\title{
Transportlīdzekḷa vadītāja bēgšanas kriminalizēšanas tiesiskie aspekti
}

\author{
Māris Garjānis \\ Rīgas Stradiña universitāte, Juridiskā fakultāte, Latvija \\ maris.garjanis@rsu.lv
}

\section{Kopsavilkums}

Šì brīža tiesiskais regulējums Latvijā par transportlīdzekḷa vadītāja bēgšanu vai par nepakḷaušanos tādas personas atkārtotai vai vairākkārtējai prasībai apturēt transportlīdzekli (par bēgšanu), kura ir pilnvarota pārbaudīt transportlīdzekḷa vadītāja dokumentus, paredz administratīvo atbildību, proti, piemēro naudas sodu transportlīdzekḷa vadìtājam no divsimt četrdesmit līdz četrsimt naudas soda vienībām un atṇem transportlīdzekḷu vadǐšanas tiesības uz pieciem gadiem.

Bēgšana var notikt ar iemeslu to darìt vai bez šāda iemesla, piemēram, pārbaudot policijas darbinieku sagatavotības līmeni vai transportlīdzekḷu tehniskās iespējas. Tà var būt saistìta 1) ar personas centieniem izvairīties no atbildïbas par iepriekš izdarìtu administratīvo pārkāpumu vai noziedzīgu nodarījumu, 2) ar personas pārsteigšanu noziedzīga nodarījuma izdarī̌̌anas brīdī vai arī 3) ar citām krimināltiesiskām sekām, piemēram, personai kāda kriminālprocesa ietvaros kā drošības līdzeklis ir piemērots apcietinājums un noteikta šìs personas meklēšana, kuras rezultātā persona tiks ievietota ieslodzījuma vietā.

Centieni izvairīities no administratīvās atbildības vai kriminālatbildības ir biežākais transportlīdzekḷa vadītāja bēgšanas iemesls, jo bēgšanas uzsākšanas brīdī vadītajam, kurš ir pieñēmis lēmumu par šādu rīcỉbu, rodas kḷūdains priekšstats par veiksmīgu bēgšanas rezultātu, kas lielākoties dažādu iemeslu dēḷ tomēr beidzas ar vajātā transportlīdzekḷ la vadìtāja notveršanu.

Apzināta transportlīdzekḷa vadītāja bēgšana, nepakḷaujoties pilnvaroto amatpersonu prasībai apturēt transportlīdzekli, galvenokārt ir saistīta ar sabiedriskās drošības un satiksmes drošības apdraudējumu, jo, vadītājam bēgot, tiek izdarīti dažādi rupji ceḷu satiksmes noteikumu pārkāpumi, kā rezultātā tiek apdraudēti citi ceḷu satiksmes dalïbnieki, tostarp mazāk aizsargātie: gājēji, velosipēdu, mopēdu un motociklu vadītāji, tiek braukts ne tikai pa cel̦iem, bet arī pa citām vietām, kas nav paredzētas transportlīdzekḷu braukšanai, proti, ietvēm, gājēju cel̦iem, velosipēdu celıiem, kā arī pa vietām, kur transportlīdzekḷu braukšanu pat nevarētu iedomāties, piemēriem, mežiem, pḷavām, skvēriem, parkiem, bērnu rotalı laukumiem. 
Ceḷu satiksmes negadỉjuma izraisiš̌anas iemesli ir dažādi, galvenokārt tie ir ațlautā braukšanas ātruma pārsniegšana un transportlīdzekḷa vadīšana, atrodoties alkohola, narkotisko, psihotropo un citu apreibinošo vielu ietekmē.

Bēgot persona vairāk uzmanības pievērš notiekošajam viṇa transportlīdzekḷa aizmugurē, kontrolējot operatīvā transportlīdzekḷa un darbinieku rīcību, tādējādi novēršoties no ceḷu satiksmes kontroles braukšanas virzienā, līdz ar to vadītājs rīkojas novēloti, savlaicīgi nesamazina transportlīdzekḷa braukšanas ātrumu, pienem kḷūdainus lēmumus. Ja transportlīdzeklis tiek vadìts, atrodoties alkohola, narkotisko, psihotropo vai citu apreibinošo vielu ietekmē, ir jārēḳinās, ka vadītāja reakcijas laiks palielinās, tādēl vadītājs uz jebkurām satiksmes situācijas izmaiṇām reagee novēloti. Vienlaikus, palielinot transportlīdzekḷa braukšanas ātrumu, vadītāja redzes leṇkis sašaurinās un veidojas redzes tuneḷa efekts, kas vadītājam liedz iespēju izvairīties no savlaicīgi prognozējamām ceḷu satiksmes situāciju izmaiṇām salīdzinājumā ar normāliem braukšanas apstākḷiem. Bēgšanas laikā transportlīdzekḷu braukšanas ātrums nereti sasniedz atzīmi $200 \mathrm{~km} / \mathrm{h}$ un pat vairāk.

Vajāšanu veicošā transportlīdzekḷa vadītājs ir privilegeètā stāvoklī attiecībā pret bēgošā transportlīdzekḷ̦a vadītāju, jo bēgošā transportlīdzekḷ vadītāja rīcība ir prognozējama, ceḷu satiksmes situācija un turpmākais braukšanas virziens redzamības attālumā ir paredzams, un tas l̦auj veiksmīgāk veikt vajāšanu.

Bēgšana parasti beidzas ar bēgošā transportlīdzekḷa vadītāja izraisītu ceḷu satiksmes negadỉjumu ar vai bez cietušām vai bojāgājušām personām. Izraisītā cel̦u satiksmes negadījuma sekas nav prognozējamas, tādēḷ, ja neviena persona necieš, tā ir veiksme.

Šì brīža tiesiskais regulējums nesasniedz Administratīvās atbildības likuma 13.pantā paredzēto soda mērḳi, proti, administratīvais sods ir ietekmēšanas līdzeklis, kas tiek piemērots administratīvo pārkāpumu izdarījušajai personai, lai aizsargātu sabiedrisko kārtību, atjaunotu taisnīgumu, sodītu par izdarīto pārkāpumu, kā arī atturētu administratīvo pārkāpumu izdarījušo personu un citas personas no turpmākas administratīvo pārkāpumu izdarī̌̌anas $[1,13$. pants $]$.

Par to, ka administratīvā soda mērḳis netiek sasniegts, liecina Valsts policijas interneta vietnē regulāri publicētie paziṇojumi par kārtējā bēgošā transportlīdzekḷa vadītāja notveršanu, aprakstot vadītāja izdarìtos cel̦u satiksmes noteikumu pārkāpumus. Šādu apgalvojumu apstiprina arī publiski pieejamie anonimizētie tiesu spriedumi, no kuriem izriet, ka vadītāju bēgšana ir bieži sastopams pārkāpums, kura iemesls ir iepriekš izdarīts administratīvais pārkāpums vai noziedzīgs nodarỉjums, un ka bēgšanas laikā tiek izraisīti ceḷu satiksmes negadījumi ar cietušām vai bojāgājušām personām vai bez tām.

Iepriekš minētais ir pietiekams pamats tam, lai lemtu par transportlīdzekḷa vadītāja bēgšanas kriminalizēšanu un vadītāja saukšanu pie kriminālatbildības par nepakḷaušanos tādas personas atkārtotai vai vairākkārtējai prasībai apturēt transportlīdzekli (par bēgšanu), kura ir pilnvarota pārbaudìt transportlīdzekḷa vadītāja dokumentus.

Atslēgvārdi: transportlīdzekḷa vadītājs, nepakḷaušanās, bēgšana, ceḷu satiksmes negadījums, ceḷu satiksmes noteikumu pārkāpums, kriminalizēšana. 
Māris Garjānis. Transportlīdzekḷa vadītāja bēgšanas

kriminalizēšanas tiesiskie aspekti

\section{levads}

Kaut gan Latvijā nav apkopotu statistikas datu par to, cik bieži transportlīdzekḷa vadītāji nepakḷaujas tādu personu atkārtotai vai vairākkārtējai prasībai apturēt transportlīdzekli (par bēgšanu), kuras ir pilnvarotas pārbaudìt transportlīdzekḷa vadìtāja dokumentus (policijas darbinieks, robežsargs vai muitas amatpersona), no Valsts policijas publiskotajiem datiem un tiesu spriedumiem ir redzams, ka bēgšana joprojām ir bieži sastopams transportlīdzekḷ vadìtāju izdarìts administratīvais pārkāpums.

Šādu secinājumu varu izdarīt, pamatojoties arī uz savu profesionālo pieredzi, pildot prokurora pienākumus Rīgas Autotransporta prokuratūrā, analizējot bēgšanas iemeslus un vērtējot bēgšanas dēl radītās sekas kriminālprocesa ietvaros.

Transportlīdzekḷa vadītāja bēgšanas aktualitāte izriet arī no nepārtrauktās sodu bardzības pārskatīšanas par šo pārkāpumu, proti, Ceḷu satiksmes likuma, kas stājies spēkā 2020. gada 1. jūlijā, 52. panta piektajā daḷā ir noteikts, ka par nepakḷaušanos personas, kura ir pilnvarota pārbaudìt transportlīdzekḷa vadītāja dokumentus, atkārtotai vai vairākkārtējai prasībai apturēt transportlīdzekli (par bēgšanu) piemēro naudas sodu transportlīdzekḷa vadītājam no divsimt četrdesmit līdz četrsimt naudas soda vienībām un atñem transportlïdzekḷ vadīšanas tiesības uz pieciem gadiem [2, 52. panta piektā dalı]. Turklāt Administratīvās atbildības likuma 16. panta otrajā daḷā ir noteikts, ka viena naudas soda vienība ir pieci euro $[1,16$. panta otrā dalı $]$.

Salīdzinot Latvijas Administratīvo pārkāpumu kodeksa regulējumu, kas zaudējis spēku 2020. gada 1. jūlijā, ar Administratīvās atbildības likuma regulējumu, kas stājies spēkā 2020. gada 1. jūlijā, redzams, ka iepriekš paredzētais naudas sods par bēgšanu mopēda vadītājam, kas bija simt septiṇdesmit euro, un cita transportlīdzekḷa vadìtājam (izn,emot velosipēda vadītāju), kas bija no tūkstoš divsimt euro līdz tūkstoš četrsimt euro, tika aizstāts ar naudas sodu jebkura transportlīdzekḷa vadìtājam (izṇemot velosipēda vadītāju) no divsimt četrdesmit līdz četrsimt naudas soda vienībām, t. i., no tūkstoš divsimt euro līdz divtūkstoš euro apmērā. Tātad maksimālā naudas soda robeža tika palielināta no tūkstoš četrsimt euro līdz divtūkstoš euro. Vienlaikus ar izmainu ieviešanu tika būtiski palielināts naudas sods mopēda vadītājam no līdzšinējiem simt septiņdesmit euro līdz minimālajam slieksnim tūkstoš divsimt euro, kā arī tika palielināts transportlīdzekḷu vadīšanas tiesību atṇemšanas sods no četriem gadiem līdz pieciem gadiem, kas piemērojams arī mopēda vadìtājam [5, 145.5panta piektā daḷa]. Vienlaikus ar izmainu ieviešanu tika atcelts sods - administratīvais arests $[1,52$. panta piektā dalı $]$.

Uz transportlīdzekḷa vadītāja bēgšanas radīto bīstamību, kas ir vērsta pret sabiedrības un satiksmes drošību, tieši norādīts Likuma "Par policiju" 14. panta trešās dal̦as 6. punktā, kurā teikts, ka policijas darbiniekam ir tiesības pielietot šaujamieroci galējas nepieciešamības situācijā, lai apturētu transportlīdzekli, nodarot tam bojājumus, ja tā vadītājs ar savu rīcību rada reālus draudus personu dzīvībai un veselībai un nepakḷaujas policijas darbinieka prasībai apstādināt transportlīdzekli un ja nav citas iespējas viṇu aizturēt $[6,14$. panta trešās daḷas 6. punkts]. Saskaṇā ar Robežsardzes likuma 18. panta 
trešās dal̦as 4. punktu arī robežsargam ir tiesības lietot šaujamieroci, lai apturētu transportlīdzekli, nodarot tam bojājumus, ja tā vadītājs ar savu rīcību rada reālus draudus robežsarga vai citu personu dzīvībai un veselïbai un nepakḷaujas robežsarga prasībai apstādināt transportlīdzekli un nav citas iespējas viṇu aizturēt [14, 18. panta trešās daḷas 4. punkts].

Šaujamieroča pielietošanas gadijjumā ir izšķirami divu veidu riski, pirmkārt, sabiedriskās drošības apdraudējums, kas tieši ir saistīts ar šaujamieroča pielietošanu, piemēram, transportlīdzekḷ vadišana, personai atrodoties ievainotā stāvoklī, otrkārt, sabiedriskās un satiksmes drošības apdraudējums, kas rodas, bēgošā transportlīdzekḷa vadìtājam izraisot cel̦u satiksmes negadỉjumu ar cietušajiem, bojāgājušajiem vai bez tiem.

Viens no pēdējiem plašu rezonansi guvušajiem bēgšanas gadỉjumiem bija transportlīdzekḷa vadītāja bēgšana no Valsts policijas un Rīgas Pašvaldības policijas darbiniekiem, kas norisinājās ceḷa posmā no Rīgas līdz Ogrei, kuras laikā tika pielietots šaujamierocis [15]. Saskaṇā ar 2020. gada 6. aprịla publikāciju Valsts policijas interneta vietnē www.vp.gov.lv 2020. gada 3. aprīlī Valsts policijas Rīgas reǵiona pārvaldes Kriminālpolicijas pārvalde Riggas Autotransporta prokuratūrai kriminālvajāšanas uzsākšanai nodevusi kriminālprocesu, kas uzsākts pret automašīnas AUDI A6 vadītāju, kurš 2019. gada 24. jūlijā Rīgā, uz Krasta ielas, atrodoties narkotisko vielu ietekmē, nepakḷāvās ceḷu policijas prasībai apturēt transportlīdzekli un uzsāka bēgšanu. Valsts policijas amatpersonas uzsāka pakaḷdzišanos, taču agresīvais autovadītājs, nepakḷaudamies policistu vairākkārtējai prasībai apturēt transportlīdzekli, turpināja braukt, apdraudot citus satiksmes dalībniekus. Pakaḷdzišanās laikā tika iesaistìti arī papildspēki. Tā turpinājās līdz pat Ogrei, kur, lai apturētu bīstamo autovadītāju, policijai nācās pielietot šaujamieroci. Pakalıldzīšanās laikā cieta viens no policistiem, kurš ar dažādām traumām tika nogādāts medicīnas iestādē, kā arī tika bojāti vairāki transportlīdzekḷi. Policijas darbinieki agresīvo autovadìtāju aizturēja. Noskaidrojot autovadītāja identitāti, tika konstatēts, ka šì persona jau ir izsludināta meklēšanā par citiem noziedzīgiem nodarījumiem. Šobrīd vīrietis izcieš cietumsodu par citu iepriekš izdarìtu noziedzīgu nodarījumu.

Kā paredzēts Krimināllikuma 262. panta ceturtajā daḷā, automašīnas AUDI A6 vadītājam tika inkriminēta noziedzīga nodarỉjuma izdarī̌̌ana par ceḷu satiksmes noteikumu vai transportlīdzekḷu ekspluatācijas noteikumu pārkāpšanu, ja to izdarījusi persona, kas vada transportlīdzekli alkohola, narkotisko, psihotropo, toksisko vai citu apreibinošu vielu ietekmē, un ja tās rezultātā cietušajam nodarīts smags miesas bojājums vai tã izraisỉjusi cilvēka nāvi un noziedzīgu nodarījumu, kā arī par uzbrukumu varas pārstāvim vai citai valsts amatpersonai sakarā ar tās likumisku dienesta darbību un par uzbrukumu personai sakarā ar tās līdzdalību noziedzīga vai cita prettiesiska nodarījuma novēršanā vai pārtraukšanā, kas paredzēts Krimināllikuma 269. panta pirmajā dạ̦ā [15].

No minētā izriet, ka transportlīdzekḷa vadītājam par bēgšanas faktu ir piemērojama tikai tobrīd spēkā esošajā Latvijas Administratīvo pārkāpumu kodeksā paredzētā administratīvā atbildība, neraugoties uz to, ka bēgošā transportlīdzekḷa apturēšanai tika pielietoti šaujamieroči, un to, ka bēgšanas laikā transportlīdzekḷa vadītājs izdarīja 
divus noziedzīgus nodarījumus, kas minēti Krimināllikuma 262. panta ceturtajā daḷā un 269. panta pirmajā dạ̦ā.

Rakstā paustais autora viedoklis ir pamatots arī ar profesionālo pieredzi bēgošu transportlīdzekḷu vadītāju aizturēšanā, tostarp ar šaujamieroču pielietošanu, pildot dienesta pienākumus Valsts policijā.

\section{Darba mērḳis}

1. Noskaidrot ar transportlīdzekḷa vadītāja bēgšanu saistīto tiesisko problemātiku.

2. Noskaidrot nepieciešamības kriminalizēt transportlīdzekḷa vadītāja bēgšanu tiesiskos aspektus.

3. Izstrādāt priekšlikumus konstatētās problemātikas risināšanai.

\section{Materiāls un metodes}

Darbā tika izmantoti nacionālie politikas plānošanas dokumenti, normatīvie akti un tiesu spriedumi.

Pētījumā ir izmantotas šādas tiesību normu interpretācijas metodes - gramatiskā, vēsturiskā, teleologiskā un sistēmiskā interpretācijas metode. Tiesību normu gramatiskā interpretācijas metode tika izmantota, lai nonāktu pie pētijuma secinājuma, pētot tiesību normu jēgu no gramatiskā viedokḷa. Vēsturiskā tiesību normu interpretācijas metode tika izmantota, lai noskaidrotu tiesību normu jēgu, ṇemot vērā apstākḷus, uz kuriem pamatojoties tā radīta,, tiesību normu attīstîbu un pilnveidošanos, attiecinot to uz pētỉjuma nosaukumā ietverto problemātiku. Teleologiskā tiesību normu interpretācijas metode tika izmantota, lai noskaidrotu tiesību normu jēgu un ar tām sasniedzamos mērḳus. Sistēmiskā tiesību normu interpretācijas metode tika izmantota, lai noskaidrotu tiesību normas jēgu saistībā ar citām tiesību normām, piemēram, ar blanketa normu, proti, pēc cel̦u satiksmes noteikumu pārkāpuma, ṇemot vērā radītās sekas, vainīgajam iestājas administratīvā atbildība vai kriminālatbildība, kas attiecīgi ir paredzēta Ceḷu satiksmes likumā vai Krimināllikumā.

Pètījuma ietvaros tika izmantotas šādas pētniecíbas metodes - datu salīdzinošā, analīzes, aprakstošā un empīiskā metode. Salīdzinošā metode tika izmantota, lai salīdzinātu pētījumā gūtos datus, atrastu tajos kopīgo un atšķirīgo. Analīzes metode tika izmantota, lai analizētu salīdzināšanas rezultātā gūtos datus, proti, kopīgo un atšḳirīgo, un rezultātus izmantotu priekšlikumu izstrādāšanā. Aprakstošā metode tika izmantota normatīvajos aktos ietverto tiesību normu un tiesu spriedumos atspoguloto faktisko apstākḷu aprakstīšanai, kas ir attiecināmi uz pētījuma priekšmetu. Empīiskā metode tika izmantota, lai pētījumā gūtu datus, kas ir balstīti uz autora profesionālo pieredzi.

Pètījuma jautājumi:

1. Kāds ir bēgšanas skaidrojums?

2. Kā Ceḷu satiksmes likumā paredzētais administratīvais sods par bēgšanu ietekmē likumā paredzēto soda mērkị?

3. Kāds ir nepieciešamības kriminalizēt bēgšanu tiesiskais aspekts? 
Māris Garjānis. Transportlīdzekḷa vadītāja bēgšanas

kriminalizēšanas tiesiskie aspekti

\section{Transportlīdzekḷa vadītāja bēgšanas tiesiskā regulējuma analīze}

Ceḷu satiksmes likuma ceturtajā un piektajā dal̦ā ir noškirti divi administratīvo pārkāpumu sastāvi, kas saistīti ar transportlīdzekḷa vadītāja nepakḷaušanos apturēt transportlīdzekli pēc pieprasījuma, proti, aplūkojamā panta ceturtajā daḷā paredzēts, ka par nepakḷaušanos tādas personas prasībai apturēt transportlīdzekli, kura ir pilnvarota pārbaudīt transportlīdzekḷa vadītāja dokumentus, piemēro brīdinājumu vai naudas sodu transportlīdzekḷ vadītājam triju naudas soda vienību apmērā $[2,52$.panta ceturtā daḷa]. Administratīvās atbildības piemērošana, piemērojamais soda veids un mērs par šādu pārkāpumu, autora ieskatā, ir pamatots un samērīgs.

Atškịiībā no aplūkojamā panta piektajā daḷā minētā administratīiā pārkāpuma sastāva panta ceturtajā daḷa minētais administratīvais pārkāpums ir saistìts ar pilnvarotās amatpersonas prasību neizpildīšanu pēc pirmreizējā pieprasījuma.

Savukārt Ceḷu satiksmes likuma piektajā dạ̣a paredzēts, ka par nepakḷaušanos tādas personas atkārtotai vai vairākkārtējai prasībai apturēt transportlīdzekli (par bēgšanu), kura ir pilnvarota pārbaudīt transportlīdzekḷa vadītāja dokumentus, piemēro naudas sodu transportlīdzekḷ va vaitājam no divsimt četrdesmit līdz četrsimt naudas soda vienībām un atñem transportlïdzekḷa vadīšanas tiesïbas uz pieciem gadiem [2, 52.panta piektā daḷa].

Autora ieskatā, administratīvās atbildības piemērošana, piemērojamais soda veids un mērs par aplūkojamā panta piektajā daḷā paredzēto pārkāpumu nav nedz pamatots, nedz samērīgs, nedz tas sasniedz Administratīvās atbildības likuma 13. pantā definēto soda mērḳi.

Ceḷu satiksmes likuma 52. panta piektajā dạ̦ā minētais administratīvais pārkāpums ir izdarāms tikai ar tiešu nodomu un aktīvu pretdarbību amatpersonu aicinājumam apturēt transportlīizekli.

Kriminālatbildības paredzēšana par transportlīdzekḷa vadītāja bēgšanu, pēc autora domām, ir samērīga un atbilstoša un tā ir salīdzināma ar Krimināllikuma 281. panta otrajā dạ̦ā un $262 .{ }^{1}$ panta otrajā daḷā paredzētajiem noziedzīgu nodarījumu sastāviem. To līdzība izpaužas apstāklī, ka tie ir noziedzịgi nodarījumi, kuru izdarīšanas iemesls ir izvairīšanās no atbildības par citu iepriekš izdarītu administratīvu pārkāpumu vai noziedzīgu nodarījumu. Šo noziedzīgo nodarījumu sastāvi ir formāli, tas nozīmē, ka nav nepieciešams, lai iestātos materiālas sekas, un noziedzīgs nodarỉjums ir uzskatāms par pabeigtu ar brīdi, kad persona uzdodas par citu personu, lai izvairītos no administratīvās atbildības vai kriminālatbildības.

Arī ceḷu satiksmes negadījuma vietas atstāšana, ja to ir izdarījis negadỉjumu izraisījušā transportlīdzekḷa vadītājs, ja viṇa izraisittajā negadījumā cietušajai personai ir nodarīti vismaz viegli miesas bojājumi, ir uzskatāms par pabeigtu noziedzīgu nodarījumu, tiklīdz persona celı satiksmes negadijuma vietu ir pametusi un nav rīkojusies atbilstoši cel̦u satiksmes noteikumu prasībām neatkarīgi no tā, vai persona vēlāk ir pieteikusies policijā vai ne. 
Abu aprakstīto noziedzīgo nodarïjumu vainas forma ir tī̌̌a, proti, noziedzīgie nodarïjumi ir izdarīti ar tiešu nodomu.

Paredzot kriminālatbildību transportlīdzekḷa vadītājam par bēgšanu, nepakḷaujoties atkārtotai vai vairākkārtējai pilnvaroto amatpersonu prasībai apturēt transportlīdzekli, noziedzīgais nodarījums būtu uzskatāms par pabeigtu ar bēgšanas uzsākšanas brīdi, nepakḷaujoties vismaz divām prasībām apturēt transportlīdzekli, neatkarīgi no vajāšanas rezultāta. Apdraudējuma objekts šajā gadījumā būtu satiksmes drošỉba.

No Ceḷu satiksmes likuma 25. panta pirmās dal̦as izriet, ka mehāniskā transportlīdzekḷa vadītāja pienākums ir uzrādīt dokumentus policijas darbiniekam, robežsargam vai muitas amatpersonai, tādējādi šis amatpersonas ir tiesīgas pieprasīt transportlīdzekḷ̣a vadītājam apturēt viṇa vadìto transportlīdzekli $[2,25$. panta pirmā daḷa].

Policijas amatpersonu tiesība apturēt transportlīdzekli izriet arī no Likuma "Par policiju" 12. panta 20. punkta, 19. panta sestās daḷas. $19 .{ }^{1}$ panta piektās daḷas, turklāt šādas tiesības ir gan Valsts policijas, gan Pašvaldỉbas policijas, gan Ostas policijas amatpersonām [6, 12. panta 20. punkts, 19. panta sestā dala, 19.1 panta piektā dal $a]$. Robežsarga tiesības apturēt transportlīdzekḷus kontrolei izriet no Robežsardzes likuma 15. panta pirmās dal̦as 1. punkta $[14,15$. panta pirmās dallas 1. punkts].

Saskañā ar Muitas likuma 14. panta otrās daḷas 3. punktu Ministru kabinets nosaka kārtību, kādā muitas amatpersona veic transportlīdzekḷa apturēšanu Latvijas Republikas muitas teritorijā muitas kontroles veikšanai un nogādā transportlīdzekli muitas iestādē muitas kontroles veikšanai [10, 14. panta otrās daḷas 3. punkts]. Savukārt muitas amatpersonu tiesības apturēt bēgoša transportlīdzekḷa vadītāju izriet arī no 2017. gada 8. augusta Ministru kabineta noteikumiem Nr. 468 "Noteikumi par atseviškiem muitas kontroles veidiem" 30. punkta, kurā paredzētas muitas amatpersonas tiesības, izmantojot Valsts ieñēmuma dienesta operatīvo transportlīdzekli ar iedegtu mirgojošu zilu bākuguni un ieslēgtu skaṇas signālu, ar skaḷruṇa palīdzību dodot atkārtotu norādījumu apturēt transportlīdzekli un nepieciešamības gadījumā piesaistot Valsts policiju $[8,30$. punkts $]$.

Aprakstīto normatīvo aktu salīdzināšana un analīze netieši norāda uz pazīmēm, kas būtu par pamatu bargākas atbildības noteikšanai transportlīdzekḷa vadītājam par bēgšanu.

\section{Kriminālatbildība kā priekšnosacijums likumā paredzētā soda mērḳa sasniegšanai}

Kaut gan transportlīdzekḷa vadītāja pienākums apturēt transportlīdzekli ir gadījumā, ja transportlīdzekḷa apturēšanu veic valsts policijas darbinieks, robežsargs vai muitas amatpersona, tiesu praksē tomēr lielākoties ir sastopami gadījumi, kas saistīti ar nepakḷaušanos tieši valsts policijas amatpersonu prasībām. Turpmāk tiks analizēti vairāki šādi gadījumi.

Ar 2018. gada 4. jūlija Rēzeknes tiesas spriedumu persona A. ir atzìta par vainīgu noziedzīgu nodarījumu izdarīšanā, kas paredzēti Krimināllikuma 262. panta pirmajā daḷā un 312. pantā, un sodīta. Pēc noziedzīgo nodarījumu kopības un spriedumu kopības 
personai A. galīgais sods noteikts - brīvỉbas atṇemšana uz 5 (pieciem) mēnešiem, atṇemot transportlïdzekḷa vadīšanas tiesības uz 3 (trīs) gadiem 8 (astoṇiem) mēnešiem un 14 (četrpadsmit) dienām.

No sprieduma aprakstošās un motīvu dal̦as ir redzams, ka persona A. vadỉja transportlīdzekli BMW, atrodoties alkohola ietekmē, bez transportlīdzekḷa vadīšanas tiesībām (transportlīdzekḷa vadǐšanas tiesības ir atṇemtas) un izvairījās no tiesību ierobežošanas soda izciešanas, kas tika noteikts ar 2015. gada 6. maija Rēzeknes tiesas spriedumu. Spriedumā teikts, ka apsūdzētā vadìtajā transportlīdzeklī noziedzīgā nodarỉjuma izdarīšanas brīdī ir atradušies četri pasažieri un ka apsūdzētais, vadot transportlīdzekli apdzīvotā vietā, ir pārsniedzis atḷauto braukšanas ātrumu, kā arī nav pakḷāies Valsts policijas darbinieku prasībai apturēt transportlïdzekli, turpinājis vadìt transportlïdzekli (bēdzis) un izraisījis ceḷu satiksmes negadījumu. Tiesa šādas darbības vērtēja kā izteiktu noziedzīgu pašpaḷāvību, kas būtiski apdraudēja citu cel̦u satiksmes dalībnieku, kā arī apsūdzētā transportlīdzekḷa pasažieru veselību un dzīvību. Tiesa vērtēja apsūdzētā rīcību kā klaji nihilistisku un sabiedriski bīstamu.

No analizētā tiesas sprieduma ir redzams, ka personas A. bēgšanas iemesls bija transportlīdzekḷa vadīšana, atrodoties alkohola ietekmē un bez transportlīdzekḷa vadīšanas tiesībām, kas ir atņemtas, un laikā, kad personai A. ir piemērots tiesību ierobežošanas sods, par ko ir paredzēta kriminālatbildība. Un no sprieduma ir redzams, ka personas A. bēgšana tika pārtraukta brīdī, kad tā izraisīja cel̦u satiksmes negadījumu [11].

Ar 2018. gada 14. septembra Rigas Apgabaltiesas Krimināllietu kolēgijas spriedumu ${ }^{1}$ krimināllietā Nr. 11520021615 ir atcelts Rīgas pilsētas Vidzemes priekšpilsētas tiesas 2018. gada 7. februāra spriedums un apsūdzētais A. L. ir atzìts par vainīgu noziedzīga nodarījuma izdarīšanā, kas paredzēts Krimināllikuma $262 .{ }^{1}$ pantā, un sodìts ar piespiedu darbu uz 120 (simt divdesmit) stundām, atṇemot tiesības vadìt transportlïdzekḷus uz 2 (diviem) gadiem par to, ka ir vadījis transportlīdzekli BMW 730 pa Duntes ielu no Tilta ielas puses Dambja ielas virzienā, Rīgā, bez transportlīdzekḷa vadīšanas tiesībām, kas ir atṇemtas, un pēc transportlīdzekḷa apturēšanas atteicās no medicīniskās pārbaudes alkohola koncentrācijas noteikšanai asinīs un narkotisko, psihotropo vielu ietekmes pārbaudes.

Analizējot spriedumu, secināms, ka persona A. L. transportlīdzekli ir apturējusi tikai pēc tam, kad A. L. vadìtā transportlīdzekḷa braukšanas trajektoriju aizškēersoja policijas dienesta transportlīdzeklis un tikai pēc cel̦u satiksmes negadỉjuma izraisīšanas ar to. Faktiski persona A. L. bēga un transportlīdzekli apturēja tikai pēc satiksmes negadījuma izraisiš̌anas, ietriecoties Valsts policijas transportlīdzeklī. No sprieduma motīvu dal̦as izriet, ka A. L. vadīja transportlīdzekli bez transportlīdzekḷa vadī̌anas tiesībām, atrodoties narkotisko vielu ietekmē, kas ir konstatēta klīniski, tādējādi secināms, ka bēgšana bija saistìta ar izvairǐšanos no kriminālatbildības par transportlīdzekḷa vadīšanu bez

1 Šajā un nākamajā analizētajā tiesu spriedumā raksta autors bija procesa virzītājs pirmstiesas kriminālprocesā un apsūdzības uzturētājs tiesā. 
transportlīdzekḷa vadīšanas tiesībām (transportlīdzekḷa vadīšanas tiesības ir atṇemtas) un atrodoties narkotisko vielu ietekmē, kas bija gan bēgšanas, gan atteikšanās no medicīniskās pārbaudes iemesls [12].

Ar 2019. gada 18. februāra Rīgas pilsētas Vidzemes priekšpilsētas tiesas spriedumu krimināllietā Nr. 11520080416 apsūdzētais A. ir atzīts par vainīgu noziedzīgu nodarījumu izdarīšanā, kas paredzēti Krimināllikuma $253 .^{2}$ panta pirmajā daḷā, 262. panta otrajā daḷā un 262. ${ }^{1}$ panta otrajā dal̦ā, un sodìts. Kā galīgais sods pēc noziedzīgu nodarījumu kopỉbas, veicot daḷeju sodu saskaitī̌sanu, A. ir noteikts - brīvības atṇemšana uz 10 (desmit) mēnešiem, atṇemot transportlīdzekḷa vadīšanas tiesības uz 5 (pieciem) gadiem, par to, ka A. vadija transportlīdzekli BMW 318, ar kuru brauca pa Kreimennu ielu no Meldru ielas puses Augusta Dombrovska ielas virzienā, Rìgā, bez transportlīdzekḷa vadīšanas tiesībām, atrodoties narkotisko vielu ietekmē, izraisīja cel̦u satiksmes negadïjumu, kurā vieglus miesas bojājumus guva persona B., pēc negadijuma izraisǐšanas A. atstāja ceļu satiksmes negadỉjuma vietu bēgot.

No sprieduma motīvu dal̦as izriet, ka personas A. bēgšanas iemesls bija saistīts ar izvairīšanos no kriminālatbildības par narkotisko vielu lietošanu gada laikā pēc administratīvā soda uzlikšanas un brīdinājuma izteikšanas un par transportlīdzekḷa vadīšanu bez transportlīdzekḷa vadīšanas tiesībām, atrodoties narkotisko vielu ietekmē. Taču ceḷu satiksmes negadījuma vietas atstāšana bija saistīta arī ar kriminālatbildības iestāšanos par miesas bojājumu nodarīšanu transportlīdzekḷa pasažierim, kas atradās personas A. vadìtajā transportlīdzeklī [13].

Ar 2019. gada 26. aprīla Zemgales rajona tiesas spriedumu apsūdzētais A. ir atzìts par vainīgu noziedzīga nodarījuma izdarīšanā, kas paredzēts Krimināllikuma 262. ${ }^{1}$ panta pirmajā daḷā, un sodīts ar brīvības atṇemšanu uz 4 (četriem) mēnešiem un transportlīdzekḷa vadīšanas tiesību atṇemšanu uz 4 (četriem) gadiem.

No sprieduma aprakstošās un motīvu dal̦as ir redzams, ka persona A. vadīja transportlīdzekli bez transportlīdzekḷa vadīšanas tiesībām (transportlīdzekḷa vadīšanas tiesības noteiktā kārtībā nav iegūtas), bēga no policijas, izraisīja ceḷu satiksmes negadijumu, nobraucot no ceḷa braucamās daḷas, un pēc negadījuma atteicās no medicīniskās pārbaudes alkohola koncentrācijas noteikšanai asinīs un narkotisko, toksisko, psihotropo, toksisko vai citu apreibinošo vielu ietekmes pārbaudes. Alkohola ietekme personai A. ir konstatēta klīniski. Secināms, ka personas A. bēgšanas iemesls bija transportlīdzekḷa vadīšana bez transportlīdzekḷa vadīšanas tiesībām un atrodoties alkohola ietekmē [18].

No analizētajiem tiesu spriedumiem ir redzams, ka tie ir saistīti ar noziedzīgu nodarījumu izdarīšanu, kas ir vērsti pret satiksmes drošîbu, taču tiesu praksē ir arī gadījumi, kad transportlīdzekḷa vadītāja bēgšana ir saistīta ar citu, smagāku, noziedzīgu nodarījumu izdarīšanu, piemēram, bēgšana pēc bruṇotas laupišanas, kā tas atspoguḷots 2015. gada 23. janvāra Latgales apgabaltiesas Krimināllietu tiesas kolēgijas spriedumā lietā Nr. 11331073813 [4]. Šādos gadijumos transportlīdzekḷa vadītāja bēgšana ir îpaši bīstama satiksmes un sabiedrības drošībai. 
Šobrīd transportlīdzekḷa vadītāja bēgšana ir administratīvs pārkāpums, nevis noziedzīgs nodarïjums, un transportlīdzekḷa vadītāja bēgšana nav neviena noziedzīga nodarījuma kvalificējošā pazīme, tādēl ir log̣iski, ka bēgšanas fakts lēmumā par personas saukšanu pie kriminālatbildības par tāda noziedzīga nodarījuma izdarīšanu, kas ir saistìts ar bēgšanu, bieži netiek atspoguḷots.

Raksta autora darba pieredzē ir bijis gadījums, kad bēgošā transportlīdzekḷa vadītāja bēgšanas laikā izraisītā ceḷu satiksmes negadījumā bojā gāja notriekts gājējs, taču nedz lēmumā par personas saukšanu pie kriminālatbildības, nedz spriedumā tas netika aprakstīts, jo bēgšana nav noziedzīga nodarījuma kvalificējošā pazīme. Apsūdzētais konkrētajā gadījumā tika saukts pie kriminālatbildības par noziedzīgu nodarījumu izdarīšanu, kas paredzēti Krimināllikuma 262. panta ceturtajā dạ̦ā, 262. ${ }^{1}$ panta otrajā dạ̦ā, $253 .{ }^{2}$ panta pirmajā daḷā un 253. panta pirmajā daḷā. Ar pirmās instances tiesas spriedumu personai tika noteikts sods pēc noziedzīgu nodarïjumu kopības brīvības atṇemšana uz 8 (astoniem) gadiem, atṇemot transportlīdzekḷa vadišanas tiesỉbas uz 5 (pieciem) gadiem, bez mantas konfiskācijas un probācijas uzraudzība uz 2 (diviem) gadiem.

Savukārt citā gadījumā pēc tikko uzsāktas bēgšanas transportlīdzekḷa vadītājs izraisija cel̦u satiksmes negadījumu, kurā bojā gāja viṇa vadītā transportlīdzekḷa pasažieris, bet pasažiere guva smagus miesas bojājumus. Ar apgabaltiesas spriedumu apsūdzētais tika sodīts par noziedzīga nodarījuma izdarī̌sanu, kas paredzēts Krimināllikuma 262. panta ceturtajā daḷā, ar brīvības atn̦emšanu uz 6 (sešiem) gadiem un 6 (sešiem) mēnešiem, atṇemot transportlīdzekḷa vadīšanas tiesỉbas uz 8 (astoṇiem) gadiem.

No šajā nodạ̣ā analizētajiem un apkopotajiem tiesu spriedumiem ir secināms, ka administratīvais sods, kas šobrīd ir paredzēts par transportlīdzekḷa vadìtāja bēgšanu, ir pārāk maigs, tādēḷ nesasniedz likumā paredzēto mērḳi un neattur pārkāpuma izdarītājus un citas personas no pārkāpumu izdarīšanas nākotnē, līdz ar to rada potenciālu sabiedrības un satiksmes drošības apdraudējumu.

N̦emot vērā minēto, tad, kriminalizējot transportlīdzekḷa vadītāja bēgšanu, tas būtu klasificējams kā noziedzīgs nodarījums ar formālu sastāvu, kura objekts ir satiksmes drošība, objektīvā puse - aktīva darbība, subjekts - transportlīdzekḷa vadītājs, subjektīvā puse - tiešs nodoms. Noziedzīga nodarījuma sastāvs būtu konstatējams ar transportlīdzekḷa vadìtāja nepakḷaušanos apturēt transportlīdzekli jau pēc otrā pieprasījuma to izdarit.

Krimināllikumā paredzētajai atbildībai par transportlīdzekḷa vadītāja bēgšanu ir jābūt tuvu tādai, kāda ir paredzēta par negadījuma vietas atstāšanu, ja negadỉjuma rezultātā ir iestājušās Krimināllikuma 260. pantā paredzētās sekas un negadỉjuma vietu ir atstājis negadijumu izraisijušā transportlīdzekḷa vadītājs, proti, brīvības atṇemšana uz laiku līdz trim gadiem vai îslaicīga brīvības atṇemšana, vai piespiedu darbs, vai naudas sods, atṇemot transportlīdzekḷa vadīšanas tiesības uz laiku līdz septiniem gadiem $[3,262.1$ panta otrā dala $]$. 
Māris Garjānis. Transportlīdzekḷa vadītāja bēgšanas

kriminalizēšanas tiesiskie aspekti

\section{Sabiedrības ieguvums}

Darbs pie ceḷu satiksmes drošības uzlabošanas un cel̦u satiksmes negadījumu novēršanas, samazinot cietušo un bojāgājušo skaitu, ir viens no Eiropas Savienības mērkiem tuvākajos gados. Šāds uzdevums ir ietverts gan Eiropas Savienības, gan Latvijas politikas plānošanas dokumentos celı satiksmes drošības jomā. Eiropas Komisijas 2011. gada 28. marta Baltajā grāmatā "Ceḷvedis uz Eiropas vienoto transporta telpu - virzībā uz konkurētspèjīgu un resursefektīvu transporta sistēmu” saistībā ar celı satiksmes drošỉbu izvirzìts ambiciozs mērḳis - līdz 2050. gadam panākt, lai uz autoceḷiem bojāgājušo skaits tuvotos nullei. Saskan̄ā ar šo uzdevumu Eiropas Savienības mērkis ir uz pusi samazināt bojāgājušo skaitu līdz 2020. gadam, tālāk turpinot proporcionālu bojāgājušo skaita samazinājumu līdz 2050. gadam.

Eiropas Komisijas 2010. gada 20. jūlija paziṇojumā Eiropas Parlamentam, Padomei, Eiropas Ekonomikas un sociālo lietu komitejai un Reǵionu komitejai "Virzoties uz Eiropas ceḷu satiksmes drošỉbas telpu: cel̦u satiksmes drošības politikas ievirzes 2011.2020. gadam", atsaucoties uz Eiropas Savienības izvirzìto mērḳi 2020. gadam par bojāgājušo un cietušo skaita samazinājumu, tiek norādīts, ka ir jānodrošina tādu pasākumu kopums, kas sabalansēti aptvers visas nozares, kuras ir tiešā vai netiešā mērā saistītas ar celı satiksmes drošîbu.

Savukārt aktuāls Latvijas nacionālais politikas plānošanas dokuments ir 2017. gada 4. aprīḷa Ministru kabineta rīkojums Nr. 180 "Par Ceḷu satiksmes drošỉbas plānu 2017.2020. gadam”. Dokumenta mērḳis ir panākt, lai 2020. gadā ceḷu satiksmes negadījumos cietušo un bojāgājušo skaits samazinātos par $50 \%$, salīdzinot ar 2010. gadu. Viens no nacionālā politikas plānošanas dokumentā paredzētajiem rīcības pasākumiem plānā paredzētā mērḳa sasniegšanai ir grozỉjumi normatīvajos aktos, lai novērstu pārkāpumus ceḷu satiksmē. Vienlaikus Ceḷu satiksmes drošības plānā ir norādīta atsauce uz Valsts policijas un Latvijas Universitātes 2015. gadā veikto pētījumu par smago ceḷu satiksmes negadījumu iemesliem, kas notikuši laika posmā no 2013. gada 1. jūlija līdz 2014. gada 30. jūnijam, un to ietekmējošiem faktoriem. Pētījumā ir arī norādīts, ka, veicot analīzi par apstākḷiem smago ceḷu satiksmes negadījuma brīdī, tika secināts - 40 \% ceḷu satiksmes negadījumu ir saistīti ar aț̣autā braukšanas ātruma pārsniegšanu, savukārt alkohola vai citu apreibinošo vielu lietošana ir bijusi par vienu no iemesliem 11 \% cel̦u satiksmes negadījumu. Lai arī tikai $11 \%$ no smagajiem cel̦u satiksmes negadỉjumiem pētījumā ietvertajā laika periodā ir izraisitas alkohola vai citu apreibinošo vielu ietekmē, secināts, ka 54,4\% no šiem vadītājiem ir jau iepriekš sodīti par braukšanu reibumā (41,7 \% motociklu, mopēdu vai motorolleru vadītāju, savukārt 58,3\% vieglā automobiḷa vadītāju) [9].

No minētā izriet, ka atḷautā braukšanas ātruma pārsniegšana un transportlīdzekḷu vadīšana alkohola ietekmē ir viens no smagu cel̦u satiksmes negadïjumu izraisǐšanas iemesliem. Savukārt no raksta iepriekšèjā nodạ̦ā analizētajiem tiesu spriedumiem izriet, ka bēgšana lielākoties ir saistīta gan ar braukšanas ātruma pārsniegšanu, gan ar transportlīdzekḷa vadīšanu, transportlīdzekḷa vadītājam atrodoties alkohola ietekmē. 
Varētu prognozēt, ka transportlīdzekḷa vadītāja bēgšanas kriminalizēšana, pirmkārt, atturēs transportlīdzekḷu vadītājus no bēgšanas, otrkārt, tā novērsīs bēgšanas dēl izraisītos cel̦u satiksmes negadījumus, tostarp ar cietušajām un bojāgājušajām personām, tādējādi, virzoties uz Eiropas Savienības politikas plānošanas dokumentā izvirzīto mērḳi, proti, panākt, lai 2050. gadā ceḷu satiksmes negadījumos bojāgājušo skaits tuvotos nullei.

\section{Secinājumi}

Transportlīdzekḷa vadītāja bēgšanas iemesli galvenokārt ir saistīti ar centieniem izvairīties no atbildības par iepriekš izdarītiem administratīviem pārkāpumiem vai noziedzīgiem nodarījumiem, par kuru izdarīšanu bieži ir paredzēta bargāka atbildība nekā par pašu bēgšanu.

Transportlīdzekḷa vadītāja rīcība - bēgšana - viṇam rada ilūziju par iespēju izvairīties no administratīvās atbildības vai kriminālatbildības, taču transportlīdzekḷa vadītāja vajāšana gandrīz visos gadījumos beidzas ar vadītāja apturēšanu un notveršanu vai ar bēgošā transportlīdzekḷa vadītāja izraisītu ceḷu satiksmes negadỉjumu ar cietušajiem, bojāgājušajiem vai bez tiem.

Satiksmes drošības apdraudējums bēgšanas laikā galvenokārt ir saistīts ar atl̦autā braukšanas ātruma pārsniegšanu, atseviškłos gadījumos braucot ar ātrumu, kas ir tuvu $200 \mathrm{~km} / \mathrm{h}$, vai bēgšanas laikā vadot transportlīdzekli, vadītājam atrodoties alkohola, narkotisko vai psihotropo vielu ietekmē, ar transportlīdzekḷa vadǐšanas tiesībām vai bez tām.

Bēgšanas kriminalizēšana palīdzēs atturēt transportlīdzekḷu vadītājus no bēgšanas un vienlaikus samazināt izraisīto ceḷu satiksmes negadijumu skaitu ar cietušajiem, bojāgājušajiem vai bez tiem, tādējādi tuvinot Latvijas satiksmes drošības rādītājus Eiropas Savienības izvirzìtajam ambiciozajam mērḳim, lai 2050. gadā nebūtu ceḷu satiksmes negadījumi ar bojāgājušām personām.

Atbildībai par transportlīdzekḷa vadītāja bēgšanu ir jābūt pielīdzināmai atbildībai, kāda ir paredzēta par ceḷu satiksmes negadījuma vietas atstāšanu, ja negadỉjuma rezultātā iestājas Krimināllikuma 260. pantā paredzētās sekas.

Kā priekšlikumu autors piedāvā Krimināllikuma XXI nodal̦u (Noziedzīgi nodarỉjumi pret satiksmes drošỉbu) papildināt ar Krimināllikuma $262 .{ }^{2}$ pantu un izteikt to šādā redakcijā:

"Par nepakḷaušanos tādas personas atkārtotai vai vairākkārtējai prasībai apturēt transportlīdzekli (par bēgšanu), kura ir pilnvarota pārbaudìt transportlīdzekḷa vadītāja dokumentus - soda ar brīvỉbas atṇemšanu uz laiku līdz trim gadiem vai ar ìslaicīgu brīvības atnemšanu, vai ar piespiedu darbu, vai ar naudas sodu, atnemot transportlīdzekḷa vadīšanas tiesības uz laiku līdz septiṇiem gadiem."

Lai sasniegtu politikas plānošanas dokumentos paredzētos mērḳus, svarīgi ir sabiedrību informēt un izglītot par to, kādas juridiskās sekas bēgšanas rezultātā iestāsies noziedzīga nodarījuma subjektam. 
Piemēram, viens no iemesliem, kādēl negadījumu izraisījušā transportlīdzekḷa vadītājs bieži izdara Krimināllikuma 262. ${ }^{1}$ panta otrajā dạ̦ā paredzēto noziedzīgo nodarījumu, atstājot cel̦u satiksmes negadījuma vietu, ja ir iestājušās Krimināllikuma 260. pantā paredzētās sekas, ir transportlīdzekḷu vadītāju nezināšana un nepietiekama izglìtotība par rīcību pēc ceḷu satiksmes negadỉjuma, ja ceḷu satiksmes negadỉjumā ir cietušas personas.

\section{Legal Aspects of Vehicle Escape Criminalisation}

\section{Abstract}

The current legal regulation in Latvia regarding the fleeing of a driver or the failure to comply with the repeated requirement of such a person to stop a vehicle (for escape), which has been authorised to check the driver's documents, provides for administrative responsibility, namely that the moped driver is subject to a fine of one hundred and seventy euros, while the driver of another vehicle (except drivers of bicycles) apply administrative arrest from ten to fifteen days, imposed fines ranging from a thousand two hundred to a thousand four hundred euros and subtract the right to drive for four years.

An escape may be caused by a reason or without it, for example, by checking the level of training of police officers or technical capabilities of vehicles. Secondly, the escape may be linked to a person's efforts to avoid liability for an administrative offence previously committed or a criminal offence or a person being surprised at the time of committing a criminal offence. Thirdly, it may be related to other criminal consequences, for example, a person who has suitable means of security within the framework of criminal proceedings - arrest and search for that person, which will result in the person being placed in custody.

Efforts to avoid administrative responsibility or criminal liability are the most frequent reasons for the driver's escape, since at the time of the start of the escape; the driver who has decided to do so has a false impression of a successful escape, which for various reasons ends in capturing the persecuted driver.

According to the Author, the deliberate escape of the driver without being subject to the requirement of authorised officials to suspend the vehicle is mainly related to a threat to public safety and road safety, as the driver is fleeing, a variety of unacceptable road traffic offences are committed, resulting in the risk of other road users, including vulnerable, pedestrian, cycling mopeds, and motorcycle drivers, not only on the roads but also in other places that are not intended for driving vehicles, namely sidewalks, pedestrian roads, cycling paths, etc., as well as in places where driving cannot even be imagined, for example, forests, meadows, squares, parks, children's playgrounds, courtyards and other places. 
Generally, the escape concludes with capturing the pursued driver immediately after the road accident he has caused.

The causes of creating a road accident vary, mainly due to over-speeding or driving the vehicle under the influence of alcohol, narcotics, psychotropic and other intoxicating substances.

When fleeing, the person pays more attention to what is happening in the rear of his vehicle, by controlling the behaviour of the operating vehicle and the personnel, thereby avoiding road traffic control in the direction of driving, so that the driver's actions are delayed, they do not reduce the speed of the vehicle in due time, make erroneous decisions, etc.

If the vehicle is driven under the influence of alcohol, narcotic, psychotropic or other intoxicating substances, it must be considered that the driver's response time is increasing, so that the driver reacts late to any change in the traffic situation.

Simultaneously, as the driving speed increases the driver's visual angle decreases and creates a visual tunnel effect that prevents the driver from avoiding timely predictable changes in road conditions compared to normal driving conditions.

During the flight, the vehicle's speed often reaches the $200 \mathrm{~km} / \mathrm{h}$ mark or even more.

The driver of the pursuing vehicle is in a more privileged position than the driver of the fleeing vehicle because the behaviour of the fleeing driver is predictable, the traffic situation and the future direction of travel within sight are predictable and allow for more successful pursuit.

The flight shall normally result in a road accident caused by the driver of the fleeing vehicle, with or without victims or fatalities. In the Author's view, the consequences of the road accident caused are not predictable; if no one suffers, it is a success.

The current legal regulation does not achieve the purpose of punishment provided for in Article 22 of the Latvian Code of Administrative Violations, namely, administrative punishment is a means of liability and is applied to educate a person who has committed an administrative violation in the spirit of observance of laws and so that the offender, as well as other persons, does not commit a new offense.

It must be regarded that the purpose of administrative penalty is not achieved, according to the statements regularly published on the website of the State Police regarding the capture of the driver of another fleeing vehicle, describing road traffic offences committed by the driver. This assertion is confirmed by publicly available anonymised court judgments, which show that the flight of drivers is a common offense caused by a previous administrative or criminal offense and that road accidents with or without victims occur during the escape.

In the opinion of the Author, there are sufficient grounds for deciding on the criminalisation of the driver's flight and the criminalisation of the driver for non-compliance with the repeated or repeated requirement of a person to suspend a vehicle (for escape) authorised to inspect the driver's documents.

Keywords: driver, disobedience, escape, road accident, traffic violation, criminalisation. 
Māris Garjānis. Transportlīdzekḷa vadītāja bēgšanas

kriminalizēšanas tiesiskie aspekti

\section{Literatūra}

1. Administratīvās atbildības likums. 25.10.2018. likums. Latvijas Vēstnesis. 225, 14.11.2018. Stājies spēkā 01.07.2020. Iegūts no: https://likumi.lv/ta/id/303007-administrativas-atbildibas-likums [sk. 28.04.2020.].

2. Ceḷu satiksmes likums. 01.10.1997. likums. Latvijas Vēstnesis. 274/276, 21.10.1997. Stājies spēkā 04.11.1997. Iegūts no: https://likumi.lv/doc.php?id=45467 [sk. 28.04.2020.].

3. Krimināllikums. 17.06.1998. likums. Latvijas Vēstnesis. 199/200, 08.07.1998. Stājies spēkā 01.04.1999. Iegūts no: https://likumi.lv/ta/id/88966-kriminallikums [sk. 28.04.2020.].

4. Latgales apgabaltiesas Krimināllietu tiesas kolēgijas 2015. gada 23. janvāra spriedums krimināllietā Nr. 11331073813.

5. Latvijas Administratīvo pārkāpumu kodekss. 07.12.1984. Latvijas Padomju Sociālistiskās Republikas Augstākās padomes un Valdības Ziṇotājs. 51, 20.12.1984. Stājies spēkā 01.07.1985. Zaudējis spēku 01.07.2020. Iegūts no: https://likumi.lv/ta/id/89648-latvijas-administrativoparkapumu-kodekss [sk. 28.04.2020.].

6. Likums par policiju. 04.06.1991. likums. Latvijas Republikas Augstākās padomes un Valdības Ziṇotājs. 31/32, 15.08.1991.; Diena. 126, 05.07.1991. Stājies spēkā 04.06.1991. Iegūts no: https:// likumi.lv/ta/id/67957-par-policiju [sk. 28.04.2020.].

7. Ministru kabineta noteikumi Nr. 279 “Cel̦u satiksmes noteikumi”. 02.06.2015. Ministru kabineta noteikumi. Latvijas Vēstnesis. 122, 27.06.2015. Stājies spēkā 01.01.2016. Pieejams: https://likumi. $\mathrm{lv} / \mathrm{ta} / \mathrm{id} / 274865$-celu-satiksmes-noteikumi [sk. 28.04.2020.].

8. Ministru kabineta noteikumi Nr. 468 "Noteikumi par atsevišḳiem muitas kontroles veidiem”. 08.08.2017. Ministru kabineta noteikumi. Latvijas Vēstnesis. 161, 15.08.2017. Stājies spējā 16.08.2017. Iegūts no: https://ikumi.lv/ta/id/292867-noteikumi-par-atseviskiem-muitas-kontroles-veidiem [sk. 28.04.2020.].

9. Ministru kabineta rīkojums Nr. 180 “Par cel̦u satiksmes drošîbas plānu 2017.-2020. gadam”. 04.04.2017. Ministrukabinetarīkojums.Latvijas Vēstnesis. 72,07.04.2017.Stājiesspēkā04.04.2017.Iegūts no: https:// likumi.lv/ta/id/289986-par-celu-satiksmes-drosibas-planu-2017-2020-gadam [sk. 30.04.2020.].

10. Muitas likums. 02.06.2016. likums. Latvijas Vēstnesis. 119, 21.06.2016. Stājies spēkā 05.07.2016. Iegūts no: https://likumi.lv/ta/id/283024-muitas-likums [sk. 30.04.2020.].

11. Rēzeknes tiesas 2018. gada 4. jūlija spriedums krimināllietā Nr. 11331047918.

12. Rīgas apgabaltiesas Krimināllietu tiesas kolēgijas 2018. gada 14. septembra spriedums krimināllietā Nr. 11520021615.

13. Rīgas pilsētas Vidzemes priekšpilsētas tiesas 2019. gada 18. februāra spriedums krimināllietā Nr. 11520080416.

14. Robežsardzes likums. 27.11.1997. likums. Latvijas Vēstnesis. 329/330, 16.12.1997.; Latvijas Republikas Saeimas un Ministru kabineta Ziṇotājs. 1, 08.01.1998. Stājies spēkā 01.01.1998. Iegūts no: https://likumi.lv/ta/id/46228-robezsardzes-likums [sk. 30.04.2020.].

15. Valsts policija. 06.04.2020. Kriminālvajāšanai nodota lieta par pērn Ogrē aizturētu autovadītāju, kurš bēga no policijas. Iegūts no: http://www.vp.gov.lv/?id=69\&said=69\&relid=16864 [sk. 28.04.2020.].

16. Valsts policija. 15.04.2020. Lieldienās ceḷu policisti noḳer meklēšanā esošu personu. Iegūts no: http://www.vp.gov.lv/?id=69\&said=69\&relid=16872 [sk. 28.04.2020.].

17. Valsts policija. 27.04.2020. Policija noḳer autovadītāju, kuru pieviḷ video spēlēs gūtās prasmes. Iegūts no: http://www.vp.gov.lv/?id=69\&said=69\&relid=16884. [sk. 28.04.2020.].

18. Zemgales rajona tiesas 2019. gada 26. aprīḷa spriedums krimināllietā Nr. 11310073018. 